\title{
П. О. ЯНОВСЬКИЙ ${ }^{1 *}$, В. П. ЯНОВСЬКА ${ }^{2 *}$, В. А. ТКАЧЕНКО ${ }^{3 *}$, С. О. МАРЦЕНЮК ${ }^{4 *}$, О. Г. ВОДЧИЦЬ ${ }^{5^{*}}$, Б. О. ПЛУЖНІКОВ ${ }^{6^{*}}$
}

$1^{*}$ Каф. військової підготовки, Національний авіаційний університет, вул. Медова, 1, Київ, Україна, 03048, тел. $+38(044)$ 24909 94, +38 (067) 40315 76, ел. пошта niklu@ukr.net, ORCID 0000-0003-4430-5386

$2^{2 *}$ Каф. економіки, маркетингу та бізнес-адміністрування, Державний університет інфраструктури та технолгій, вул. Івана Огієнка, Київ, Україна, 03049, тел. +38 (044) 59151 21, +38 (098) 21200 10, ел. пошта v_yanovska@ukr.net, ORCID 0000-0002-0648-3643

$3^{*}$ Каф. військової підготовки, Національний авіаційний університет, вул. Медова, 1, Київ, Україна, 03048, тел. +38(044) 24909 94, ел. пошта uva74@ukr.net, ORCID 0000-0002-4507-6039

4* Каф. військової підготовки, Національний авіаційний університет, вул. Медова, 1, Київ, Україна, 03048, тел. $+38(044)$ 24909 94, +38 (095) 36725 51, ел. пошта sergmetall@bigmir.net, ORCID 0000-0002-0984-7895

$5^{*}$ Каф. військової підготовки, Національний авіаційний університет, вул. Медова, 1, Київ, Україна, 03048, тел. +38(044) 24909 94, ел. пошта kataza@i.ua, ORCID 0000-0002-3602-654X

$6^{*}$ Каф. військової підготовки, Національний авіаційний університет, вул. Медова, 1, Київ, Україна, 03048, тел. +38(044) 24909 94, +38 (095) 36725 51, ел. пошта ел. пошта boral1@ukr.net, ORCID 0000-0002-0444-6427

\section{МЕТОДИКА МІНІМІЗАЦІї МІСЯЧНИХ ВИТРАТ НА ФУНКЦОНУВАННЯ ВАНТАЖНОГО ЗАЛІЗНИЧНОГО ТРАНСПОРТУ В УКРАЇНI}

Метою статті є розробка методики мінімізації місячних витрат для обгрунтування реалізації раціональних організаційно-економічних рішень щодо підвищення якості транспортного обслуговування вантажовласників і функціонування вантажного залізничного транспорту. Методологія дослідження розкриває економічну сутність транспортного процесу через врахування витрат залізниць на виконання початкових операцій на станціях навантаження, переміщення вантажу дільницями, виконання всього комплексу операцій на технічних станціях та на станціях вивантаження, а також витрат на переміщення порожніх вагонів. Зазначений підхід обумовлений тим, що якість транспортного обслуговування вантажовласників залежить не лише від тривалості доставки вантажів в пункти призначення, а і від величини витрат на їх транспортування, що визначає ціну будь-якого товару в пункті споживання, отже задача скорочення транспортної складової вартості товарів $\epsilon$ комплексною і важливою для залізничного транспорту та вантажовласників. Результати. Як свідчать наведені узагальнення, в ринкових умовах задача підвищення ефективності доставки вантажів повинна вирішуватись завдяки не лише технічного і технологічного удосконалення магістрального залізничного транспорту, а і - промислового залізничного транспорту, де середній простій вагонів зазвичай перебільшує чотирнадцять діб. Промислові підприємства майже не займаються розвитком власної транспортної інфраструктури, а часто використовують вантажні вагони залізниць, як склади на колесах через економічно необгрунтовану малу плату за користування вагонами, яка $є$ у багато разів меншою за величину доходу залізниць від кожного використаного вантажовласником вагона в перевезеннях. Тому назрів час на державному рівні терміново впровадити компромісну систему управління вантажними ресурсами з урахуванням інтересів як клієнтури, так і залізниць та виконанням детальних техніко-економічних розрахунків для різних можливих варіантів технічного і технологічного розвитку промислового і магістрального залізничного транспорту. Оригінальність та практична цінність представленого дослідження полягає в чіткій побудові функціоналу місячних експлуатаційних витрат на доставку вантажів, який передбачає поетапне визначення витрат на виконання всіх технологічних операцій протягом всього періоду транспортування.

Ключові слова: ланка; ефективність; взаємодія; прискорення; резерв; експлуатаційні витрати; ремонт; експлуатація; обіг вагона; початкові операції; кінцеві операції; заробітна плата; продуктивність.

\section{Вступ}

Важливою ланкою транспортної системи держави є транспорт промислових підприємств, де зароджується і гаситься основна маса вантажопотоків. Тому узгодженість і чіткість його роботи обумовлює технологічний ритм основного виробництва і створює необхідні передумови для стійкої роботи магістрального транс- порту і єдиної транспортної системи держави. Ефективність експлуатації промислового транспорту визначається рівнем його технічного і технологічного розвитку, ступенем узгодженості роботи з різними видами транспорту і взаємодії виробництва 3 магістральним залізничним транспортом. Однак матеріально-технічна база промислового транспорту на багатьох підприємствах значно відстає від підприємств, які він 
обслуговує, і магістрального транспорту. Усунення цих диспропорцій є важливим джерелом росту продуктивності праці.

Підвищення якості роботи залізничного транспорту і його ефективності перш за все пов'язано з освоєнням наявних технічних засобів, їх удосконаленням, збільшенням провізної і пропускної спроможності на перевантажених напрямках і прискоренням процесу перевозок. Уже протягом тривалого періоду часу спостерігаються значні коливання обсягів перевізної роботи, що вимагає впроваджувати в практику сучасні форми і методи організації транспортного процесу з використанням передового досвіду провідних країн світу і досягнень науковотехнічного прогресу.

\section{Мета}

Метою статті є розробка методики мінімізації місячних витрат для обгрунтування реалізації раціональних організаційно-економічних рішень щодо підвищення якості транспортного обслуговування вантажовласників і функціонування вантажного залізничного транспорту.

\section{Методологія}

При розробці методики мінімізації місячних витрат на перевезення вантажів залізничним транспортом взято до уваги пріоритетні напрямки розвитку залізного транспорту України, окреслені Стратегією розвитку залізничного транспорту на період до 2020 року, затвердженої розпорядженням Кабінету Міністрів України від 16.12.2009 р. № 1555-р. Також враховано положення Концепції і Програми реструктуризації залізничного транспорту України, а також пакету Директив ЄC 91/440, наказів і нормативних документів ПАТ «Українська залізниця».

Дослідження в ринкових умовах транспортного процесу проводиться вченими нашої держави та інших країн. Практичні результати опубліковані в наукових працях таких вчених: Ф. Кочнєва, М. Правдіна, М. Федотова, М. Галатченка, М. Стефанова, В. Негрея, І. Тіхомірова, М. Іловайського, Ю. Кулаєва, Н. Терьошиної, А. Смехова, С. Резера, Д. Ломотька, С. Нагорного, В. Шиша, А. Котенка, Т. Бутько, С. Альошинського, Д. Козаченка, В. Мироненка, В. Самсонкіна, В. Бобровського, С. Панченко, М. Устенко, В. Івашкевич, P. Isaac, A. Campbell, D. Seidenglanz, T. Nigrin, J. Dujka, F. Kurosaki, M. Singh та ін. [0-0].

Особливий інтерес вантажовласників і транспортних організацій в сучасних економічних умовах викликає прискорення доставки вантажів [0]. Питання прискорення доставки вантажів в ринкових умовах до цих пір не отримали достатньо глибокої розробки. В той же час вони мають велике значення для підприємств, кожної залізниці, інших видів транспорту і всієї економіки в цілому. Від своєчасної перевозки сировини, палива, обладнання і швидкого відправлення готової продукції за призначенням в великому ступені залежать економічні показники підприємств, ефективність функціонування всієї економіки.

Значення прискорення доставки вантажів полягає ще в тому, що воно не тільки скорочує час перевезення матеріальних цінностей суспільства, а і $\epsilon$ важливим резервом підвищення продуктивності праці, а також ефективного використання рухомого складу. Тому знаходження можливих резервів і раціональних шляхів прискорення доставки вантажів $є$ актуальною задачею не лише для залізниць, а й для вантажовласників. Враховуючи цю обставину, пошук ефективних рішень слід здійснювати 3 використанням логістичних підходів в дослідженні вирішальних ланок існуючих транспортнологістичних систем, розробці прогресивних технологій в перевізному процесі залізниць $[0,0,0]$.

\section{Результати}

В умовах затяжної кризи для забезпечення економічної рівноваги в нашому суспільстві роль залізничного транспорту стає особливою в системі суспільного відтворення і зміцнення взаємозв'язків між галузями. Крім того, частка транспортних витрат в собівартості продукції в сучасних умовах значна, що висуває якісно нові вимоги до організації перевізного процесу на залізницях. Для цього необхідно вирішити багато ключових проблем, які мають місце в усіх залізничних підрозділах, провести їх технічну модернізацію, впровадити новітні технології, забезпечити раціональне управління експлуатаційними витратами з метою підвищення ефективності функціонування вантажного залізничного транспорту [0].

Прогрес в техніці і технології залізниць здійснює великий вплив на якість транспортного обслуговування економіки [0], а в результаті - на ефективність виробництва і перевізного процесу [0]. Від рівня економічних показників експлуатаційної роботи залізниць залежить можливість і доцільність використання тих чи інших сучасних засобів і новітніх технологічних процесів. Тому в сучасних складних умовах наявності великого дефіциту фінансових 
ресурсів важливою задачею для залізниць $є$ мінімізація місячних експлуатаційних витрат на функціонування вантажного залізничного транспорту:

$$
\mathrm{E}_{\text {функц }}=\mathrm{E}_{\text {орг }}^{\text {пер }}+\mathrm{E}_{\text {орг }}^{\text {peм.p. }}+\mathrm{E}_{\text {орг }}^{\text {pex.iнфp }} \rightarrow \min ,
$$

де $\mathrm{E}_{\text {орг }}^{\text {пер }}$ - експлуатаційні витрати на організацію перевезень вантажу протягом місяця;

$\mathrm{E}_{\text {орг }}^{\text {peм..c }}$ - місячні експлуатаційні витрати на організацію ремонту рухомого складу;

$\mathrm{E}_{\text {орг }}^{\text {peм.інр }}$ - експлуатаційні витрати на організацію ремонту інфраструктури за місяць.

Для оцінки можливих експлуатаційних витрат на доставку вантажу слід використати такий функціонал (згідно місячного плану перевезень):

$$
\mathrm{E}_{\mathrm{B}}=\sum_{i=0}^{n} \sum_{j=0}^{m} C_{i j} X_{i j}
$$

при

$$
\sum_{j=0}^{m} X_{i j}=Q_{i} ; \sum_{i=0}^{n} X_{i j}=Q_{i} ;
$$

де $X_{i j}$ - планова кількість вантажів, які необхідно перевезти за місяць;

$i=1,2,3, \ldots, n-$ кількість вагонів певного парку (фактична або необхідна);

$j=1,2,3, \ldots, m$ - кількість локомотивів (фактична або необхідна) для здійснення перевезень;

$C_{i j}$ - вартість переміщення 1 т конкретного вантажу;

$Q_{i}$ - місячний вантажопотік, млн т.

Цю задачу краще вирішити методами лінійного програмування. Всі види експлуатаційних витрат $\mathrm{E}_{\text {в }}$ для зручності здійснення розрахунків $\mathrm{i}$ забезпечення необхідної точності результату слід розділити на шість блоків із врахуванням відмінностей технологій протягом перевізного процесу у відповідності до рис. 1.

\section{Повний рейс, $\ell$}



Рис. 1. Схема обігу вагона

Ці 6 блоків витрат формуються починаючи від першого навантаження до нового навантаження, a їх сума виражається наступним чином:

$$
\begin{aligned}
\mathrm{E}_{\text {в }}=\mathrm{E}_{\text {нав }} & +\sum_{k=1}^{k} \mathrm{E}_{\text {рух }}^{\text {нав }}+\sum_{l=1}^{l} \mathrm{E}_{\text {тех ст }}^{\text {нав }}+\mathrm{E}_{\text {вив }}+ \\
+ & \sum_{p=1}^{p} \mathrm{E}_{\text {рух }}^{\text {пор }}+\sum_{r=1}^{r} \mathrm{E}_{\text {тех ст }}^{\text {пор }},
\end{aligned}
$$

де $\mathrm{E}_{\text {нав }}$ - витрати на виконання початкових операцій на станції навантаження;

$$
\sum_{k=1}^{k} \mathrm{E}_{\mathrm{pyx}}^{\text {нав }}-\text { витрати від переміщення вантажу }
$$

дільницями $k$ від станції навантаження до станції вивантаження;

$$
\sum_{l=1}^{l} \mathrm{E}_{\text {тех. ст }}^{\text {нав }}-\text { витрати на проходження вантажу }
$$

$l$ технічних станцій в вантажних поїздах до станції вивантаження;

$\mathrm{E}_{\text {вив }}$ - витрати на виконання кінцевих операцій на станції вивантаження;

$$
\sum_{p=1}^{p} \mathrm{E}_{\mathrm{pyx}}^{\text {пор }}-\text { витрати на переміщення } p \text { дільни- }
$$
цями порожніх вагонів до станції нового (повторного) навантаження;

$$
\sum_{r=1}^{r} \mathrm{E}_{\text {тех. ст }}^{\text {пор }}-\text { витрати на проходження } r \text { техніч- }
$$
них станцій порожніми вагонами.

Перший блок витрат - експлуатаційні витрати на виконання початкових операцій на станції навантаження $\mathrm{E}_{\text {нав }}$ мають такі складові. 
Експлуатаційні витрати на виконання операцій на станції навантаження, пов'язані із тривалістю простоїв вагонів:

$$
\mathrm{E}_{\text {ваг }}^{\text {прост }}=\frac{Q_{\text {міс }}^{\text {пл }}}{q_{\text {ст }}} \cdot t_{\text {ван }} \cdot e_{\text {в-г }},
$$

де $Q_{\text {мiс }}^{\text {пл }}$ - плановий обсяг перевезень вантажів на місяць, млн. т;

$q_{\mathrm{cr}}$ - статичне навантаження, т;

$t_{\text {ван }}-$ тривалість знаходження вагонів на ста-

нції навантаження (фактично або згідно 3 технологічним процесом), год.;

$e_{\text {в-г }}-$ вартість вагоно-години, грн.

3 врахуванням імовірного характеру процесів, що протікають на вантажних станціях, тривалість знаходження вагонів $t_{\text {ван }}$ слід визначати із врахуванням не лише як випадкової величини тривалості вантажних операцій, подачі i прибиранні вагонів із вантажного фронту (ВФ) i оформлення перевізних документів $(\tau)$, а i середнього часу очікування $t_{\text {оч }}$, величина якого враховує завантаження навантажувальнорозвантажувальних машин (НРM), середню тривалість вантажної операції із групою вагонів $\tau$, кількість НРМ- $Z$, годинну продуктивність HРM- $q$, обсяг вантажопереробки ВФ в тоннах на добу, робочий час використання НРМ- $T_{\mathrm{p}} \mathrm{i}$ час роботи маневрового локомотива $-T$, тобто слід враховувати $t_{\text {ван }}=\tau+t_{\text {оч }}$.

Використання цих залежностей дає можливість 3 врахуванням конкретних умов роботи ВФ і вантажної станції здійснювати перевірку достатності НРМ і маневрових засобів для виконання планового обсягу перевезень $Q_{\text {мic }}^{\text {пл }}$ вантажною станцією.

Експлуатаційні витрати, пов'язані із виконанням маневрової роботи щодо обслуговування на станції навантаження вантажопотоку $Q_{\text {мic }}^{\text {пr }}$ слід визначати за формулою:

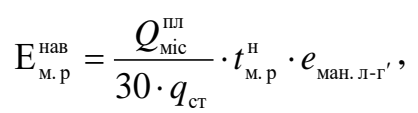

де $t_{\mathrm{m} . \mathrm{p}}^{\mathrm{H}}-$ норматив часу на виконання маневрової роботи, що приходиться на один вагон, годин;

$e_{\text {ман.л-г' }}-$ вартість маневрової локомотивогодини, грн.

Оцінку експлуатаційних витрат окремо на вантажні операції (навантаження або вивантаження) необхідно здійснювати наступним чином:

$$
\mathrm{E}_{\mathrm{H}(\mathrm{B})}^{\mathrm{cT}}=\frac{Q_{\text {міс }}^{\text {Пл }}}{30 \cdot q_{\mathrm{c \tau}} \cdot K_{\text {под }}} \cdot t_{\mathrm{H}(\mathrm{B})}^{\mathrm{H}} \cdot e_{\mathrm{B}-\mathrm{\Gamma}},
$$

де $K_{\text {под }}$ - кількість подач і прибирань вагонів за добу;

$t_{\mathrm{H}(\mathrm{B})}^{\mathrm{H}}-$ норматив тривалості вантажної операції із групою вагонів, годин.

Аналітичним чином можна визначити витрати на виконання кінцевих операцій на станції вивантаження $\mathrm{E}_{\text {вив }}$.

Другий блок витрат - експлуатаційні витрати на переміщення вантажу $k$ дільницями від станції навантаження до станції вивантаження визначаються методом витратних ставок. Залежні від розмірів руху експлуатаційні витрати кожної групи визначаються множенням величини конкретного показника на відповідну одиничну витратну ставку. Сума добутків складає загальні експлуатаційні витрати.

1) Витрати на пробіг навантажених вагонів (на вагоно-кілометри):

$$
\mathrm{E}_{\mathrm{B}-\mathrm{kM}}^{\text {нав }}=\frac{Q_{\text {мiс }}^{\text {пл }}}{30 \cdot q_{\text {ст }}} \cdot \sum_{k=1}^{k} l_{k} \cdot e_{\mathrm{B}-\mathrm{kM}},
$$

де $l_{k}$ - довжина $k$-ї дільниці, км;

$e_{\text {в-км }}$ - одинична витратна ставка одного вагоно-кілометра, грн.

2) Витрати на вагоно-години навантажених вагонів:

$$
\mathrm{E}_{\text {в-год }}^{\text {нав }}=\frac{\sum n S_{\text {нав }}}{S_{\text {в }}} \cdot 24 \cdot e_{\text {в-год }},
$$

де $\sum n S_{\text {нав }}$ - пробіг навантажених вагонів, вагкм;

$S_{\text {в }}$ - середньодобовий пробіг навантажених вагонів, км/доба;

$e_{\text {в-год }}$ - одинична витратна ставка однієї вагоно-години.

3) Витрати на локомотиво-кілометри:

$$
\mathrm{E}_{\text {л-км }}=\frac{Q_{\text {міс }}^{\text {пл }}}{30 \cdot q_{\text {ст }} \cdot m_{\text {сер }}} \cdot \sum_{k=1}^{k} l_{k} \cdot\left(1+\beta_{\text {доп }}\right) e_{\text {л-км }},
$$

де $m_{\text {сер }}$ - середня кількість вагонів у складі поїзда, ваг.;

$\beta_{\text {доп }}$ - коефіцієнт допоміжного пробігу;

$e_{\text {л-км }}-$ одинична витратна ставка одного поїзного локомотиво-кілометра. 
4) Витрати на локомотиво-години:

$$
\begin{gathered}
\mathrm{E}_{\text {лгго }}=\frac{Q_{\text {міс }}^{\text {пл }}}{30 \cdot q_{\text {ст }} \cdot m_{\text {сер }} \cdot S_{\text {л }}} \times \\
\times \sum_{k=1}^{k} l_{k} \cdot\left(1+\beta_{\text {доп }}\right) \cdot e_{\text {л-год }},
\end{gathered}
$$

де $S_{\text {л }}$ - середньодобовий пробіг поїзного локомотива, км/доба;

$e_{\text {л-год }}$ - одинична витратна ставка однієї локомотиво-години.

5) Витрати на бригадо-години локомотивних бригад:

$$
\begin{gathered}
\mathrm{E}_{\text {бр-год }}=\frac{Q_{\text {міс }}^{\text {пл }}}{30 \cdot q_{\text {ст }} \cdot m_{\text {сер }} \cdot V_{\text {д }}} \times \\
\times \sum_{k=1}^{k} l_{k} \cdot\left(1+\beta_{\text {доп }}\right) \cdot e_{\text {бр -год }},
\end{gathered}
$$

де $V_{\text {д }}$ - дільнична швидкість, км/год;

$e_{\text {бр-год }}-$ одинична витратна ставка однієі бригадо-години.

6) Витрати на тонно-кілометри брутто вагонів і локомотивів визначаються таким чином:

- тонно-кілометри брутто локомотивів визначаються:

$$
\begin{gathered}
\sum P l_{\text {брутто }}^{\text {лок }}=\frac{Q_{\text {міс }}^{\text {пा }}}{30 \cdot q_{\text {ст }} \cdot m_{\text {сер }} \cdot V_{\text {д }}} \times \\
\times \sum_{k=1}^{k} l_{k} \cdot\left(1+\beta_{\text {доп }}\right) Q_{\text {л }}
\end{gathered}
$$

де $Q_{\text {л }}$ - маса локомотива, т;

- тонно-кілометри брутто вагонів:

$$
\sum P l_{\text {бругто }}^{\text {ваг }}=\frac{Q_{\text {мic }}^{\text {пл }}}{30} \cdot \sum_{k=1}^{k} l_{k} \cdot\left(1+\frac{q_{\mathrm{T}}}{q_{\text {ст }}}\right),
$$

де $q_{\text {т }}$ - маса тари вагона, т;

- витрати на тонно-кілометри складуть:

$$
\begin{gathered}
\mathrm{E}_{\text {т-км }}=\left(\sum P l_{\text {бругто }}^{\text {лок }}+\sum P l_{\text {брутто }}^{\text {ваг }}\right) \cdot e_{\text {т-км }}= \\
=\sum P l_{\text {брутто }} \cdot e_{\text {т -км }}
\end{gathered}
$$

де $\cdot e_{\text {т-км }}$ - одинична витратна ставка одного тонно-кілометра.

7) Витрати на електроенергію (паливо) на тягу поїздів:

$$
\mathrm{E}_{\mathrm{e}(\mathrm{I})}=\sum P l_{\text {бругто }}^{\text {лок }} \cdot \Phi^{\mathrm{e}(\mathrm{I})} \cdot e_{\text {пал }}^{\mathrm{e}(\mathrm{I})} \times 10^{-4},
$$

де $\Phi^{\mathrm{e}(\text { п) }}-$ фактичні витрати умовного палива в
кВт/год або кг на 10000 т-км брутто;

$e_{\text {пал }}^{\text {e(п) }}-$ вартість одного кВт/год або кг умовного палива, грн.

Крім того, витрати на переміщення вантажів (вагонів) дільницями протягом навантаженого рейсу можна визначати за допомогою методики [0].

Третій блок витрат - експлуатаційні витрати на проходження вантажу $l$ технічних станцій в навантажених поїздах до станції вивантаження складаються із наступних складових.

1) Витрати на вагоно-години транзитних вагонів у парках технічних станцій:

$$
\mathrm{E}_{\mathrm{B}-\text { год }}^{\mathrm{Tc}}=\frac{Q_{\text {міс }}^{\text {пл }}}{30 \cdot q_{\mathrm{cт}}} \cdot\left[\sum_{i=1}^{K_{\text {бп }}} t_{\text {бп }}^{i}+\sum_{i=1}^{K_{\text {зп }}} t_{\text {3п }}^{i}\right] \cdot e_{\text {л-км }},
$$

де $K_{\text {бп }}$ - кількість технічних станцій, які проходять навантажені вагони за час обігу вагона без переробки, станцій;

$$
\sum_{i=1}^{K_{\text {бп }}} t_{\text {бп }}^{i} \text { - сумарний час знаходження транзит- }
$$

ного вагонопотоку без переробки на $K_{\text {бп }}$ технічних станціях;

$K_{\text {зп }}$ - кількість технічних станцій, які проходять навантажені вагони за час обігу вагона 3 переробкою, станцій;

$\sum_{i=1}^{K_{\text {зn }}} t_{3 \text { iा }}$ сумарний час знаходження транзитного вагонопотоку з переробкою на $K_{\text {зп }}$ технічних станціях.

2) Витрати на локомотиво-години поїзних локомотивів у складі поїздів, які знаходяться на технічних станціях:

$$
\begin{aligned}
& \mathrm{E}_{\text {лггод }}^{\mathrm{Tc}}=\frac{Q_{\text {мic }}^{\text {пI }}}{30 \cdot q_{\text {ст }} \cdot m_{\text {сер }}} \times
\end{aligned}
$$

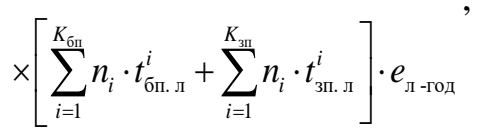

де $n_{i}$ - кількість локомотивів у кожному $i$-му поїзді;

$$
\sum_{i=1}^{K_{\text {би }}} n_{i} \cdot t_{\text {бп.л }}^{i}-\text { сумарний час знаходження ло- }
$$
комотивів на технічних станціях при їх проходженні з поїздами без переробки, год;

$\sum_{i=1}^{K_{\text {зn }}} n_{i} \cdot t_{\text {зплл }}^{i}$ - сумарний час знаходження поїзних локомотивів на технічних станціях при їх проходженні з поїздами з переробкою, год.

3) Витрати на бригадо-години локомотивних бригад у складі поїздів у парках технічних 
станцій:

$$
\begin{gathered}
\mathrm{E}_{\text {бр-год }}=\frac{Q_{\text {млі }}^{\text {пा }}}{30 \cdot q_{\text {ст }} \cdot m_{\text {сер }}} \times \\
\times\left[\sum_{i=1}^{K_{\text {бп }}} n_{\text {бр. } i} \cdot t_{\text {бп. бр }}^{i}+\sum_{i=1}^{K_{\text {зू }}} n_{\text {бр. } i} \cdot t_{\text {зп. бр }}^{i}\right] \cdot e_{\text {бр -год }},
\end{gathered}
$$

де $n_{\text {бр. } i}-$ кількість локомотивних бригад у кожному $i$-му поїзді;

$$
\sum_{i=1}^{K_{\text {бп }}} n_{\text {бр. } i} \cdot t_{\text {бп. бр }}^{i}-\text { сумарний час знаходження }
$$

локомотивних бригад на технічних станціях при їх проходженні з поїздами без переробки, год;

$$
\sum_{i=1}^{K_{\text {зи }}} n_{\text {бр. } i} \cdot t_{\text {зп.бр }}^{i}-\text { сумарний час знаходження ло- }
$$

комотивних бригад на технічних станціях при їх проходженні з поїздами з переробкою, год.

4) Витрати на локомотиво-години маневрової роботи, що виконується на технічних станціях маневровими локомотивами:

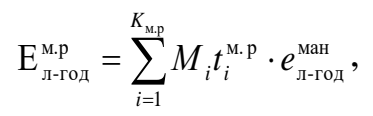

де $K_{\text {м.р }}$ - кількість технічних станцій, на яких виконується маневрова робота із транзитними поїздами, станцій;

$M_{i}-$ кількість маневрових локомотивів, які обслуговують транзитні поїзди на технічних станціях;

$t_{i}^{\text {м.p }}$ - час роботи на $i$-ій технічній станції маневрових локомотивів, год;

$e_{\text {л-год }}^{\text {ман }}-$ одинична витратна ставка однієї маневрової локомотиво-години, грн.

Значний вплив на експлуатаційні витрати має використання рухомого складу, яке можна оцінити за допомогою системи якісних показників.

Аналіз складових комплексного якісного показника обігу вантажного вагона $\theta_{\text {в }}$ проведений у [0] свідчить, що питома вага кожної з них стабілізувалась в останні роки на рівні: тривалість знаходження вантажного вагона у чистому русі складає $13,3 \%$, на проміжних станціях $-2,1 \%$, під вантажними операціями $-39,8 \%$, на технічних станціях - 44,8 \%. Практика організації перевізного процесу свідчить, що впливати на величини перших двох складових з метою ïx скорочення у залізниць мало можливостей.

Важливий напрямок діяльності залізничного транспорту у тісній співдружності із підприєм- ствами $\epsilon$ скорочення тривалості вантажних операцій (з врахуванням міжопераційних простоїв) шляхом забезпечення якісної взаємодії виробництва і транспорту. Але для вирішення цієї важливої задачі недостатньо лише зусиль залізниць. Реальний стан на станціях навантаження свідчить про необхідність системної і кардинальної перебудови взаємовідносин галузей економіки 3 транспортними підприємствами, ліквідувавши системно, перш за все, інвестування високорентабельних компаній приватного бізнесу за рахунок втрат залізничного транспорту.

Враховуючи найбільшу величину питомої ваги у тривалості обігу вагона простою на технічних станціях актуальною задачею сучасності $\epsilon$ обгрунтування раціональних параметрів сортувальних станцій, окремі їх складові слід досліджувати в реальних умовах не ізольовано, а в комплексі з використанням системного підходу. Це пов'язано $з$ тим, що зміна технічних i технологічних параметрів одного із елементів впливає на роботу всієї станції. Крім того, реалізація будь-яких раціональних рішень в роботі станцій мережі вимагає тривалого періоду часу. Тому сумарні приведені витрати для розвитку всієї станції слід визначати в річному періоді по трьох основних іiі підсистемах: по парку відправлення, комплексу формування, сортувальному парку і приймальному парку. Стійка і якісна робота сортувальної станції забезпечується при умові, коли інтенсивність обслуговування $\mu$ вхідного потоку, який надходить в конкретну підсистему станції, повинна бути більшою або дорівнювати інтенсивності обслуговування потоку, який надходить в попередню систему. Отже, необхідно досягти для кожної сортувальної станції реалізації такого співвідношення $[0,0,0]$ :

$$
\mu_{\text {вх. д }} \mu_{\text {пा }} \leq \mu_{\text {г }} \leq \mu_{\text {сп }} \leq \mu_{\text {вф }} \leq \mu_{\text {по }} \leq \mu_{\text {вих.д }} .
$$

Сумарні витрати на утримання і розвиток парку відправлення $\mathrm{E}_{\text {пв }}$, по комплексу формувань $\mathrm{E}_{\text {кф }}$, по сортувальному парку $\mathrm{E}_{\text {сп }} \mathrm{i}$ витрат по парку прийому $\mathrm{E}_{\text {пा }}$ та їх складові визначаються за методикою наведеною у [13].

Четвертий блок витрат - експлуатаційні витрати на виконання кінцевих операцій на станції вивантаження $\mathrm{E}_{\text {вив }}$ мають такі складові, як $\mathrm{i} \mathrm{E}_{\text {нав }}$. Тому ці витрати необхідно визначати за формулами (4)-(6).

П'ятий блок витрат - експлуатаційні витрати на переміщення $p$ дільницями порожніх 
вагонів до станції нового (повторного) навантаження в цілому визначають як суму витрат по всіх дільницях, які входять в маршрут переміщення за наступними складовими витратами:

1) Витрати на пробіг порожніх вагонів (вагоно-кілометри):

Слід розглядати випадки:

- на станції вивантаження $K_{\text {здв }}=2$, порожні вагони зі станції не відправляються, витрати на вагоно-кілометри порожніх вагонів відсутні;

- на станції вивантаження $K_{\text {здв }}=1$, всі порожні вагони відправляються зі станції, витрати на вагоно-кілометри порожніх вагонів максимальні. Реальні витрати залежать від фактичної кількості порожніх вагонів $n_{\text {пор }}$ :

$$
\begin{aligned}
\mathrm{E}_{\text {в-км }}^{\text {пор }}= & \alpha_{i}^{\text {пор }} \frac{Q_{\text {міс }}^{\text {пл }}}{30 \cdot q_{\text {ст }}} \cdot \sum_{k=1}^{k} l_{p} \cdot e_{\text {в-км }}= \\
= & \sum n \cdot S_{\text {пор }} \cdot e_{\text {в-км }},
\end{aligned}
$$

де $\alpha_{i}^{\text {пор }}-$ питома вага порожніх вагонів, відправлених зі станції вивантаження, ваг.;

$l_{p}$ - довжина $p$-ї дільниці, км.

2) Витрати на вагоно-години порожніх вагонів:

$$
\mathrm{E}_{\text {в-год }}^{\text {пор }}=\frac{\sum n S_{\text {пор }}}{V_{\text {д }}}\left(1+\frac{\sum t_{\text {тех }}^{\text {ст }} \cdot V_{\text {д }}}{\sum l_{p}}\right) \cdot e_{\text {в-год }},
$$

де $\sum t_{\text {тех }}^{\text {ст }}$ - тривалість стоянок транзитних поїздів на технічних станціях, год.

3) Витрати на локомотиво-кілометри:

$$
\mathrm{E}_{\text {л-км }}^{\text {пор }}=\frac{\sum n S_{\text {пор }} \cdot q_{\text {т }}}{Q_{\text {п }}} \cdot M,
$$

де $Q_{\text {п }}$ - маса поїзда із порожніх вагонів, т.;

$M$ - кількість поїзних локомотивів, локомотивів.

4) Витрати на локомотиво-години:

$$
\mathrm{E}_{\text {логод }}^{\text {пор }}=\frac{\sum n S_{\text {пор }} \cdot q_{\text {т }}}{Q_{\text {п }} \cdot V_{\text {д }}}\left(1+\frac{\sum t_{\text {тех }}^{\text {ст }} \cdot V_{\text {д }}}{2 \sum l_{p}}\right) e_{\text {Л-год }} \cdot
$$

5) Витрати на бригадо-години локомотивних бригад:

$$
\mathrm{E}_{\text {бр-год }}^{\text {пор }}=\frac{\sum n S_{\text {пор }} \cdot q_{\text {т }}}{Q_{\text {п }} \cdot V_{\text {д }}}\left(1+\frac{\sum t_{\text {бр }} \cdot V_{\text {д }}}{\sum l_{p}}\right) e_{\text {бр-год }},
$$

де $\sum t_{\text {бр }}$ - час роботи локомотивних бригад по прийому і здачі локомотива на станціях основного депо, станціях обороту локомотивів і зміни бригад.

6) Тонно-кілометри брутто порожніх вагонів:

$$
\sum P l_{\text {т-км }}^{\text {пор }}=n S_{\text {пор }} \cdot q_{\text {т }}\left(1+\frac{P}{Q}\right) .
$$

7) Витрати на електроенергію (паливо) на тягу поїздів із порожніх вагонів:

$$
\mathrm{E}_{\mathrm{e}(\text { пा }}^{\text {пор }}=\sum P l_{\text {т-км }}^{\text {пор }} \cdot \Phi^{\mathrm{e}(\text { п) }} \cdot e_{\text {пал }}^{\mathrm{e} \text { (п) }} \times 10^{-4},
$$

Шостий блок витрат - експлуатаційні витрати на проходження порожніх вагонів $r$ технічних станцій при слідуванні їх від станції вивантаження до станції нового (повторного) навантаження слід використовувати формули (16)-(19) $з$ врахуванням питомої ваги порожніх вагонів $\alpha_{i}^{\text {пор }}$ і середньої величини кількості вагонів у складі поїзда із порожніх вагонів $m_{\text {сер }}^{\text {пор }}$

Експлуатаційні витрати на організацію ремонту вантажних вагонів $\mathrm{E}_{\text {орг }}^{\text {рем.в }}$ визначаються у відповідності до [0]. Для виконання цієї роботи 3 вагонами враховують прямі витрати на матеріали, запчастини $\mathrm{E}_{\text {мат. зап }}^{\text {рем. }}$ заробітну плату робітників $\mathrm{E}_{3 . п}^{\text {рем.в }}$, соціальні заходи $\mathrm{E}_{\mathrm{c.3}}^{\text {рем.в }}$, паливо $\mathrm{i}$ електроенергію для технологічних цілей $\mathrm{E}_{\text {п.е }}^{\text {рем.в }}$, тобто:

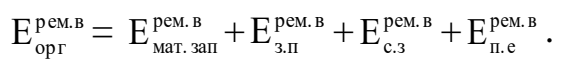

Місячні експлуатаційні витрати на заробітну плату і соціальні заходи (20 \%) виробничих працівників визначаються [0]:

$$
\mathrm{E}_{\text {з.п.з.с }}^{\text {рем.в }}=1,2 \cdot T \cdot Ч_{\mathrm{P}} \cdot \Phi_{\text {р.ч }} \cdot \frac{K_{\text {прем }}}{12},
$$

де $K_{\text {прем }}$ - коефіцієнт, який враховує премії.

Місячні експлуатаційні витрати на матеріали, запасні частини і їх транспортування визначаються таким чином:

$$
\mathrm{E}_{\text {мат. зап }}^{\text {рем. }}=\frac{1}{12} \cdot\left[\sum_{i=1}^{n} M_{i}+\mathrm{T}_{\mathrm{p} . i}\right],
$$

де $i=1,2,3 \ldots, n-$ види поточних ремонтів локомотивів протягом року;

$M_{i}$ - загальна вартість матеріалів на річну програму ремонту локомотивів $i$ - го виду;

$\mathrm{T}_{\mathrm{p} . i}$ - транспортні витрати на доставку матеріалів і запасних частин для виконання ремонту $i$-го виду. 
Витрати за місяць на матеріали і запасні ча-

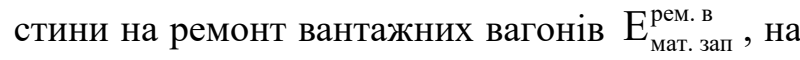
заробітну плату робітників 3 ремонту вагонів $\mathrm{E}_{\text {з.п }}^{\text {рем. в } ; ~ в і д р а х у в а н н я ~ н а ~ с о ц і а л ь н і ~ з а х о д и ~} \mathrm{E}_{\mathrm{c.3.}}^{\text {рем.в }}$, на електроенергію, що витрачається ; на технологічні потреби $\mathrm{E}_{\mathrm{e}}^{\text {рем. в } п р и ~ р е м о н т і ~ в а г о н і в, ~ а ~}$ також при виконанні ремонту локомотивів

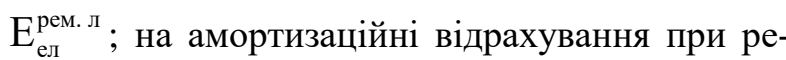

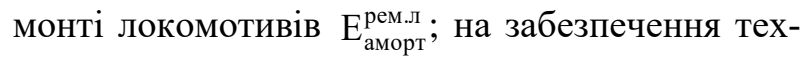
нологічного процесу 3 ремонту локомотивів (вартість опалення $\mathrm{E}_{\text {опал }}^{\text {рем. }}$, освітлення $\mathrm{E}_{\text {осв }}^{\text {рем. л }} \mathrm{i}$ прибирання робочих приміщень $\mathrm{E}_{\text {приб }}^{\text {рем. }}$ ) на охорону праці $\mathrm{E}_{\text {ох.пр }}^{\text {рем. }}$ i накладні витрати $\mathrm{E}_{\text {накл }}^{\text {рел. }}$ визначаються за формулами, наведеними у [0].

Після розрахунків усіх складових експлуатаційних витрат, пов'язаних із ремонтом рухомого складу, i, виходячи із річного обсягу ремонту, визначається собівартість ремонту вагонів і локомотивів. В розрахунках враховуються всі понесені виробником витрати.

До матеріально-технічної бази залізничного транспорту відноситься інфраструктура, яка включає до себе споруди залізничної колії, склади різноманітного призначення, виробничі будівлі, різні машини, обладнання, пристрої безпеки: автоблокування, лінії зв'язку, контактна мережа та інше.

Експлуатаційні витрати на ремонт інфраструктури залізниць пов'язані із забезпеченням утримання у працездатному стані названих споруд, визначається таким чином.

Сума експлуатаційних витрат на ремонт елементів інфраструктури складається із [0]:



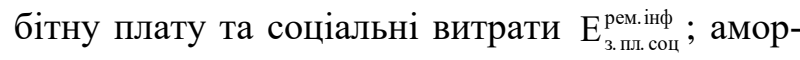


троенергію $\mathrm{E}_{\text {ел. }}^{\text {рем ін }}$; інші витрати $\mathrm{E}_{\text {інш. }}^{\text {рем.ін }}$.

Місячні експлуатаційні витрати на матеріали для ремонту елементів інфраструктури визначаються [0]:

$$
\sum_{i=1}^{n} \mathrm{E}_{\text {мат }}^{\text {рем. інф }}=\frac{1}{12} \cdot 0,015 \cdot \sum_{i=1}^{n} K_{i},
$$

де $i=1,2,3 \ldots, n-$ конкретний $i$-й елемент інфраструктури;

$K_{i}$ - капітальні витрати за рік на придбання обладнання для ремонту $i$-го елемента інфра- структури.

Місячні експлуатаційні витрати на заробітну плату і соціальні виплати (20 \%) визначаються:

$$
\mathrm{E}_{\text {3.пл.соц }}^{\text {рец інф }}=1,2 \cdot 1,05 \cdot 3_{\text {міс }} \cdot Ч_{\mathrm{P}},
$$

де 1,05 - коефіцієнт, що враховує необхідність підмін на період відпусток;

$3_{\text {міс }}$ - середньомісячна заробітна плата одного працівника.

Місячна величина амортизаційних відрахувань складає:

$$
\mathrm{E}_{\text {аморт }}^{\text {рем інф }}=0,12 \cdot \mathrm{H}_{\mathrm{a}} \cdot K_{\text {бал }}^{i},
$$

де $K_{\text {бал }}^{i}$ - балансова вартість основних фондів $i$ го елемента інфраструктури.

Місячні експлуатаційні витрати на оплату споживання електроенергії визначаються:

$$
\mathrm{E}_{\text {ел }}^{\text {рем. інф }}=P \cdot t_{\text {м }} \cdot k_{\text {втр }} \cdot T_{\text {ен }},
$$

де $P$ - сумарна потужність обладнання;

$t_{\text {м }}$ - кількість годин роботи обладнання на місяць (при безперервному цілодобовому енергоживленні - 720 год.);

$k_{\text {втр }}-$ коефіцієнт втрат електроенергії в установках електроживлення $(1,12)$;

$T_{\text {ен }}$ - тариф на електроенергію, грн/кВт-год.

До складу інших витрат включають витрати на сплату рахунків за послуги сторонніх організацій, витрати на банківське обслуговування, поточний ремонт виробничих приміщень. В розрахунках приблизно можна цю суму витрат приймати в розмірі 70 \% величини фонду заробітної плати виробничого персоналу.

\section{Оригінальність та практична цінність}

Представленого дослідження полягає в чіткій побудові функціоналу місячних експлуатаційних витрат на доставку вантажів, який передбачає поетапне визначення витрат на виконання всіх технологічних операцій протягом всього періоду транспортування.

\section{Висновки}

Якість обслуговування вантажовласників суттєво залежить від тривалості доставки вантажів до пунктів призначення, від якої залежать витрати залізничного транспорту. Вони в свою чергу визначають транспорту складову в ціні будь-якого товару в пунктах споживання. Тому задача скорочення транспортної складової в ціні товару є актуальною не лише для спожива- 
чів, але і для виробників і залізниць, а також вона $є$ комплексною, що вимагає докладання зусиль усіх учасників транспортного процесу.

В ринкових умовах при обмежених ресурсах підприємств залізничного транспорту необхідність прискорення доставки вантажів набуває особливої ваги. Але для прискорення транспортного процесу необхідно в нього вкладати фінансові ресурси вантажовласниками і перевізником разом. В сучасних тяжких умовах, в яких працює залізничний транспорт, що підтверджується високим рівнем зносу його основних фондів (прострочення капітального ремонту на 27 \% магістральних ліній, знос тягових підстанцій складає $67 \%$, а контактної мережі - $65 \%$, магістральних електровозів - $92 \%$, тепловозів - $99 \%$, вантажних вагонів - понад $90 \%$ ) ці проблеми є особливо гострими та такими, що потребують термінового вирішення.

На підприємствах промисловості залізничний транспорт перебуває у занепаді і не розвивається, що призводить до дефіциту вагонів. Середній простій вагонів на під'ізних коліях складає 12-14 і більше діб. Вагони часто використовуються підприємствами як склади на колесах через необгрунтовано малу плату за користування вагонами, яка в 24 рази менша величини доходу залізниць від кожного використаного вантажовласником вагона в перевезеннях.

Такий стан в транспортному процесі держави вимагає розробляти для кожної партії вантажу логістичний ланцюг доставки вантажів (ЛЛДВ) 3 виконанням детальних технікоекономічних розрахунків для різних можливих варіантів технічного і технологічного розвитку промислового i магістрального залізничного транспорту. Виконання таких розрахунків слід здійснювати 3 використання представленої методики мінімізації місячних витрат на функціонування вантажного залізничного транспорту.

\section{БІБЛІОГРАФІЧНИЙ СПИСОК}

1. Нагорный, Е. В. Совершенствование технического обслуживания вагонов на сортировочных станциях / Е. В. Нагорный, И. И. Хаба. - Киев : Техни- ка, 1987. - 94 с

2. Осьминин, А. Т. Управление эксплуатационной работой железных дорог и качеством перевозок / А. Т. Осьминин. - Москва : Транспорт, 2008. - 450 с.

3. Панченко, С. В. Забезпечення конкурентоспроможності залізничного транспорту України в умовах індустріальної трансформації економіки / С. В. Панченко // Вісник економіки транспорту і промисловості. - 2018. - № 62 дод. (Спецвипуск). - С. 5-6.

4. Практичний посібник з упровадження технолого-економічної моделі перевізного процесу. ЦД0079 : Затв.: Наказ Укрзалізниці від 17.12.08 за № 550-Ц. - Київ : НВП Поліграфсервіс, 2009. - 270 с.

5. Сич, Є. М. Економіка вагонного господарства / Є. М. Сич, Н. І. Богомолова, В. П. Гудкова, В. М. Кислий. - Київ : Видавництво «Логос», 2007. - 327 с.

6. Устенко, М. О. Логістичні технології як фактор забезпечення якості обслуговування споживачів транспортних послуг / М. О. Устенко, В. С. Івашкевич // Вісник економіки транспорту і промисловості. - 2018. - № 61. - С. 95-102.

7. Яновський, П. О. Методичні основи забезпечення якісної взаємодії виробництва і транспорту / П. О. Яновський // Залізничний транспорт України. - 2013. - № 5/6. - С. 104-111.

8. Fumio Kurosaki, Manoj Singh (2016). Comparison of three models for introducing competition in rail freight transport. Transportation Research Procedia. - 2016. - Vol. 14. - P. 2820-2829. - doi : 10.1016/j.trpro.2016.05.348

9. Isaac, P., \& Campbell, A. M. (2017). Shortest path problem with arc failure scenario. EURO Journal on Transportation and Logistics. - 2017. - 6(2). P. 139-163. - doi:10.1007/s13676-015-0092-6

10. Seidenglanz D., Nigrin, T., \& Dujka, J. (2015). Regional Railway Transport in Czech, Austrian and German Decentralised and Regionalised Transport Markets. Review of Economic Perspectives. - 2015. 15(4). - P. 431-450. - doi: 10.1515/revecp-2015-0029

11. Yanovsky P., Yanovska V., Lytvynenko S., Nesterenko H., Lytvynenko L. (2018) Principles of the Feedback Action in Local Elements of Rail Interaction Yard. International Journal of Engineering \& Technology. 2018. - Vol. 7 (4.3). - P. 196-200.

Стаття рекомендована до публікаиії д.т.н., проф. Козаченко Д. М. (Україна)

Надійшла до редколегії 15.11.2018.

Прийнята до друку 19.11.2018.

П. А. ЯНОВСКИЙ, В. П. ЯНОВСКАЯ, В. А. ТКАЧЕНКО, С. А. МАРЦЕНЮК, О. Г. ВОДЧИЦЬ, Б. О. ПЛУЖНИКОВ

\section{МЕТОДИКА МИНИМИЗАЦИИ МЕСЯЧНЫХ РАСХОДОВ НА ФУНКЦИОНИРОВАНИЕ ГРУЗОВОГО ЖЕЛЕЗНОДОРОЖНОГО ТРАНСПОРТА В УКРАИНЕ}

Целью статьи является разработка методики минимизации месячных расходов для обоснования реали- 
зации рациональных организационно-экономических решений по повышению качества транспортного обслуживания грузовладельцев и функционирования грузового железнодорожного транспорта. Методология исследования раскрывает экономическую сущность транспортного процесса с учётом расходов железных дорог на выполнение начальных операций на станциях погрузки, перемещение груза участками, выполнение всего комплекса операций на технических станциях и на станциях выгрузки, а также расходов на перемещение порожних вагонов. Указанный подход обусловлен тем, что качество транспортного обслуживания грузовладельцев зависит как от продолжительности доставки грузов в пункты назначения, так и от величины затрат на их транспортировку, которая определяет цену любого товара в пункте потребления, следовательно задача сокращения транспортной составляющей стоимости товаров является комплексной и важной для железнодорожного транспорта и грузовладельцев. Результаты. Как свидетельствуют приведенные обобщения, в рыночных условиях задача повышения эффективности доставки грузов должна решаться благодаря, не только техническому и технологическому совершенствованию магистрального железнодорожного транспорта, но и промышленного железнодорожного транспорта, где средний простой вагонов обычно превышает четырнадцать суток. Промышленные предприятия почти не занимаются развитием собственной транспортной инфраструктуры, а часто используют грузовые вагоны железных дорог, как склады на колесах через экономически необоснованную малую плату за пользование вагонами, которая во много раз меньше величины доходов железных дорог от каждого использованного грузовладельцем вагона в перевозках. Поэтому назрело время на государственном уровне срочно внедрить компромиссную систему управления грузовыми ресурсами с учетом интересов, как клиентуры, так и железных дорог, и выполнением детальных технико-экономических расчетов для различных возможных вариантов технического и технологического развития промышленного и магистрального железнодорожного транспорта. Оригинальность и практическая ценность представленного исследования заключается в четком построении функционала месячных эксплуатационных расходов на доставку грузов, предусматривающего поэтапное определение затрат на выполнение всех технологических операций в течение всего периода транспортировки.

Ключевые слова: звено; эффективность; взаимодействие; ускорение; резерв; эксплуатационные расходы; ремонт; эксплуатация; оборот вагона; начальные операции; конечные операции; заработная плата; производительность.

P. YANOVSKY, V. YANOVSKA, V. TKACHENKO, S. MARTSENYUK, A. VODCHYTS, B. PLUZHNIKOV

\section{TECHNIQUE FOR MINIMIZATION OF MONTHLY EXPENDITURES FOR FUNCTIONS-ONIATION OF CARGO RAILWAY TRANSPORT IN UKRAINE}

The purpose of the article is to develop a methodology for minimizing monthly expenses to justify the implementation of rational organizational and economic decisions to improve the quality of transport services for cargo owners and the operation of freight rail transport. The research methodology reveals the economic nature of the transport process, taking into account the costs of railways to perform initial operations at loading stations, moving cargo sections, performing the whole complex of operations at technical stations and unloading stations, as well as the costs of moving empty cars. This approach is due to the fact that the quality of transport services for cargo owners depends both on the duration of delivery of goods to destinations and on the cost of transporting them, which determines the price of any goods at the point of consumption, therefore the task of reducing the transport component of the cost of goods is complex and important for railway transport and cargo owners. Findings. As the generalizations show, in market conditions, the task of increasing the efficiency of cargo delivery should be solved not only by technical and technological improvement of the main railway transport, but also by industrial railway transport, where the average simple wagons usually exceed fourteen days. Industrial enterprises almost do not develop their own transport infrastructure, and often use railroad freight cars as warehouses on wheels through an economically unreasonable small fee for using railcars, which is many times smaller than the income of railways from each railcar used by the cargo owner in transportation. Therefore, the time is ripe at the state level to urgently introduce a compromise system for managing cargo resources, taking into account the interests of both customers and railways, and the implementation of detailed technical and economic calculations for various possible options for technical and technological development of industrial and mainline transport. The originality and practical value of the presented research consists in a clear construction of the functionality of monthly operating costs for the delivery of goods, providing for the phased determination of the costs of performing all technological operations during the entire period of transportation.

Keywords: link; efficiency; interaction; acceleration; reserve; operating costs; repairs; exploitation; car turnover; initial operations; final operations; wage; performance. 